\title{
Ordonanse królewskie we Francji
}

Mimo że polscy autorzy nie unikają zagadnienia ordonansów królewskich we Francji ${ }^{1}$, podawane $\mathrm{w}$ nich informacje mają charakter fragmentaryczny i do tej pory kwestia ta nie doczekała się w rodzimej literaturze jednolitej charakterystyki. Niezależnie więc od braku nowatorstwa poniższych uwag, opartych na dorobku

${ }^{1}$ M.in. J. Bardach (red.), Historia państwa i prawa Polski, Warszawa 1981, t. III, s. 153; E. Borkowska-Bagieńska, Historia prawa sądowego, Warszawa 2010, s. 29; A. Dziadzio, Powszechna historia prawa, Warszawa 2008, s. 137-141; S. Grzybowski, Dzieje prawa, Wrocław - Warszawa - Kraków - Gdańsk 1981, s. 106 i 169; K. Koranyi, Powszechna historia państwa i prawa, Warszawa 1966, t. III, s. 289-290; K. Koranyi, Powszechna historia prawa, oprac. K. Sójka-Zielińska, Warszawa 1976, s. 239-240; B. Lesiński, W. Rozwadowski, Historia prawa, Warszawa - Poznań 1980, s. 232; T. Maciejewski, Historia powszechna ustroju i prawa, Warszawa 2015, s. 427; S. Płaza, Historia prawa w Polsce na tle porównawczym, cz. II: Polska pod zaborami, Kraków 2002, s. 56 i 162; M. Sczaniecki, Powszechna historia państwa i prawa, Warszawa 1997, s. 249-250; K. Sójka-Zielińska, Historia prawa, Warszawa 2011, s. 63-64. Pewne podane w niektórych z tych publikacji informacje wymagają przy tym zgłoszenia przeze mnie poglądu odrębnego. Za zdecydowanie nieprawdziwe należy uznać zastosowane przez B. Lesińskiego i W. Rozwadowskiego określenia ordonansów Ludwika XIV jako „częściowych”, „drobniejszych” czy „wycinkowych”; B. Lesiński, W. Rozwadowski, op.cit. Podobnie za całkowicie nieprawdziwe należy uznać odnoszące się m.in. do wydanych w latach 1667-1681 ordonansów stwierdzenie, iż ,wszystkie te akty legislacyjne [...] nie zawierały w pełni charakterystycznych cech kodeksu [...], podkreślanych w dzisiejszej nauce prawa i realizowanych w nowoczesnych kodyfikacjach"; S. Grzybowski, op.cit., s. 169. Wyjaśniam to $\mathrm{w}$ niniejszej publikacji. Trudno także zgodzić się z twierdzeniem, iż wydanie ordonansu z Villers-Cotterêts z 1539 r. stanowiło inspirację do opracowania przez Jean'a Imberta jego słynnego dzieła Institutiones forenses, jego pierwsza edycja ukazała się bowiem w $1535 \mathrm{r}$. (Institutionum forensium Galliae pene totius quae moribus regitur communium libri quatuor, auctore Joanne Imberto Rupellano Fonteniensi causidico, Parisiis 1535). Por. K. Koranyi, Powszechna historia prawa, oprac. K. Sójka-Zielińska, s. 240; K. Sójka-Zielińska, op.cit., s. 63. 
literatury francuskiej ${ }^{2}$, stosowne wydaje się uporządkowanie niniejszego zagadnienia na potrzeby czytelnika polskiego.

Pojęcie ordonansów królewskich we Francji nie jest bowiem do końca jednoznaczne i obejmuje szereg aktów królewskiego stanowienia prawa, na podstawie których powstawały regulacje prawne pełniące merytorycznie funkcje ustawy. Występowały pod różnymi nazwami: ordonanse (ordonnances), edykty (édits), deklaracje (déclarations) i patenty (lettres patentes). Miały one przy tym jednakowy charakter i tę samą moc obowiązującą. Najczęściej nazwa „ordonans” stosowana była w przypadku obszernego aktu obejmującego swym zakresem różnego rodzaju kwestie; ,edykt” przeznaczony był dla regulacji określonej instytucji; „deklaracja” natomiast stanowiła ustawę mającą co do zasady na celu objaśnienie i interpretację przepisów wcześniej wydanych, niejednokrotnie jednak zawierającą nowe regulacje, choć o znaczeniu drugorzędnym; w końcu ,patenty” miały najczęściej charakter podkreślający pewne partykularności. Rozróżnienia te miały

Na mocy wspomnianego ordonansu również nie „wprowadzono” procesu inkwizycyjnego (tak: K. Koranyi, Powszechna historia państwa i prawa, t. III, s. 289; K. Koranyi, Powszechna historia prawa, oprac. K. Sójka-Zielińska, s. 239; T. Maciejewski, op.cit.). Jego znaczenie w zakresie procedury karnej było z pewnością niezmiernie doniosłe, zdefiniowano bowiem na jego mocy naczelne zasady postępowania, na jego postanowieniach opierali się także w przeważającej mierze autorzy ordonansu z 1670 r. Do przejścia jednak od procedury akuzatoryjnej, ustnej i publicznej do inkwizycyjnej, pisemnej i tajnej dochodziło w drodze długotrwałego procesu trwającego od XIII do XVI w., a ordonans z 1539 r. stanowił tej ewolucji zwieńczenie. Por. A. Esmein, Histoire de la procédure criminelle en France et spécialement de la procédure inquisitoire depuis le XIII e siècle jusqu'a nos jours, Paris 1882, s. vii oraz 135 i n. Tytuł wydanego w 1681 r. Ordonnance de la marine, należy thumaczyć jako Ordonans o marynarce (inaczej: T. Maciejewski, op.cit.), a nie Ordonans o handlu morskim - jedynie w księdze III regulował instytucje handlu morskiego (ale nie tylko). Por. A. Klimaszewska, Code de commerce-francuski Kodeks handlowy z 1807 r., Gdańsk 2011, s. 56-60. Problematyczna też wydaje się wzmianka o „trzech wielkich ordonansach” pojawiająca się u M. Sczanieckiego, op.cit., chociaż autor zastosował „m.in.”.

${ }^{2}$ Literatura ta częściowo przytaczana była przeze mnie m.in. w następujących publikacjach: A. Klimaszewska, Ordonans o handlu ladowym z 1673 r. (Kodeks Savary'ego), „Czasopismo Prawno-Historyczne”, t. LXI, z. 1/2009, s. 103-124; idem, Code de commerce...; A. Klimaszewska, M. Mosakowski, Code noir - u źródeł ordonansu Ludwika XIV w sprawie niewolników, Gdańsk 2013; A. Klimaszewska, Wizja procedury cywilnej w uzasadnieniach i raportach do projektu Code de procédure civile z 1806 r., „Czasopismo Prawno-Historyczne”, t. LXVI, z. 1/2014, s. 263 i n.; idem, The Ordinance of 1667 - Ideology of Modern Codification as a Political Tool of Louis XIV, „Wrocław Review of Law, Administration \& Economics”, t. V, nr 1 (2015), s. 128-140; idem, Z dziejów francuskiego prawa cywilnego. „Rozporzadzenia” pierwszego prezydenta Parlamentu paryskiego Guillaume'a de Lamoignona, „Czasopismo Prawno-Historyczne”, t. LXVIII, 1/2016, s. 11-28; idem, Francuski Kodeks procedury cywilnej z 1806 r. - kodeks Napoleona Bonaparte czy Ludwika XIV?, „Czasopismo Prawno-Historyczne”, t. LXIX, z. 1/2017, s. 11-19. Opracowanie kompletnej bibliografii wymagałoby jednak odrębnej monografii. Nie jest to celem niniejszej publikacji. 
jednak wyłącznie znaczenie terminologiczne, a nie prawne, i nie były zbyt restrykcyjnie przestrzegane.

Wszystkie akty tego typu wydawane były w zbiorach (Recueils). Wspomnieć należy przede wszystkim: (1) Ordonnances des roys de France de la troisième race, recueillies par ordre chronologique, zwane również potocznie Collection des Ordonnances du Louvre. Kolekcja publikowana była sukcesywnie od 1723 r. pod redakcją Eusèbe'a de Laurière'a, Denisa-Françoisa Secousse'a, Louisa-Guillaume'a de Vilevault, Louisa Georgea Oudarta Federixa de Brèquigny, Armanda-Gastona Camusa, Amédée de Pastoreta i Jeana-Marie Pardessusa. Początkowo edycję wydawano z inicjatywy i upoważnienia kanclerza. Po utworzeniu jednak Instytutu Francji to on przejął patronat w tym zakresie i pod kierownictwem działającej w jego ramach Akademii Inskrypcji i Literatury Pięknej doszło do wydania 21 tomów, obejmujących okres do rządów Ludwika XII (ostatni dokument jest z listopada 1514 r.). Następnie dzieło przejęła Akademia Nauk Moralnych i Politycznych, która opublikowała dokumentację z różnego rodzaju prac przygotowawczych. Ta obszerna kolekcja, nie pozbawiona wprawdzie błędów i braków, jest niemniej jednak najlepszym zbiorem w stosunku do okresu, który obejmuje. (2) Recueil général des anciennes lois françaises, depuis l'an 420 jusqu'à la Révolution de 1789, contenant la notice des principaux monuments des Mérovingiens, des Carlovingiens et des Capétiens, et le texte des ordonnances, édits, déclarations, lettres patentes, règlemens, arrêts du Conseil etc., de la troisième race, qui ne sont pas abrogés, ou qui peuvent servir, soit à l'interprétation, soit à l'histoire du droit public et privé, wydawany pomiędzy 1821 a 1833 r. przez Françoisa-André Isamberta, Athanase'a-Jeana-Légera Jourdana, Decrusy'ego i Alphonse'a-Honoré Taillandiera, najczęściej znany pod nazwiskiem tego pierwszego. W pracach nad trzema tomami (XI-XIII) uczestniczył także Armet. W sumie wydano ich 29. W stosunku do okresu pokrywającego się z Kolekcją Ordonansów zbiór jest zdecydowanie mniej kompletny niż ta ostatnia, którą co do zasady powiela i do której odsyła, zadowalając się w niektórych przypadkach podaniem jedynie daty wydania lub tytułu niektórych dokumentów bez przytoczenia treści. W zamian za to obejmuje okres aż do dnia 5 maja $1789 \mathrm{r}$.

Wśród tego obszernego materiału legislacyjnego wyróżnia się ordonanse o charakterze szczególnym (spéciales), regulujące pojedyncze kwestie, i ordonanse o charakterze ogólnym (générales), stanowiące akty dotyczące szerokiego spektrum zagadnień lub wręcz szczegółowe kodeksy. Ostatnią kategorię ordonansów, ordonanse o charakterze ogólnym, podzielić można na dwie grupy: wydawane od XIV do XVII wieku (I) i tzw. wielkie ordonanse Ludwika XIV i XV (II).

I. Ordonnances générales wydawane na przestrzeni od XIV do XVII wieku, niejednokrotnie uporządkowane były w przemyślany sposób i zawierały światłe dyspozycje zarówno o charakterze ogólnym, jak i szczegółowym. Były to przede wszystkim 
ordonanse wydawane w celu ,reformy państwa” (réforme de l'État), na co wielokrotnie wskazywano już w samym tytule. W konsekwencji zawierały dyspozycje dotyczące różnorodnych kwestii z zakresu administracji. Wydawano je w celu zwalczania sygnalizowanych nadużyć. Zazwyczaj jednak dotykały tylko wybranych zagadnień dotyczących każdego z nich. Nie miały charakteru kodyfikacji, a jedynie reform częściowych. Najczęściej, ale jednak nie zawsze, wydawane były po zwołaniu Stanów Generalnych, w efekcie postulatów artykułowanych w sporządzanych w trakcie ich posiedzeń zeszytach skarg (cahiers de doléances). Zawsze jednak ich głównym redaktorem był kanclerz, na czym wówczas, między innymi, polegała jego funkcja.

Za początek serii tego typu aktów uznaje się wydany w 1318 r. ordonans Filipa V Wysokiego ${ }^{3}$. Istotny wpływ miały również ordonanse wydawane w okresie panowania Jana II Dobrego po różnych posiedzeniach Stanów Generalnych ${ }^{4}$ oraz promulgowany za rządów Karola VI Ordonnance cabochienne (1413 r. $)^{5}$. Na ich mocy wprowadzono znaczące ograniczenia władzy królewskiej. W czasie panowania Karola VII największym osiągnięciem był zawierający 125 artykułów ordonans z Montils-lès-Tours z 1454 r. ${ }^{6}$ Wydany został w wyniku ustaleń podjętych w trakcie uroczystych konsultacji ze Zgromadzeniem Notablów i stanowił pewnego rodzaju program reform, które monarchia pragnęła zrealizować (m.in. w zakresie wymiaru sprawiedliwości) ${ }^{7}$. Pod koniec XV w. promulgacji doczekały się kolejne dwa znaczące ordonanse, których wydanie uzgodniono na posiedzeniu Stanów Generalnych w 1484 r.: Ordonnance sur le fait de la justice z lipca 1493 r. ${ }^{8}$ (111 artykułów) oraz zawierający 162 artykuły ordonans z Blois wydany w marcu 1498 r. ${ }^{9}$ W okresie rządów Franciszka I w 1539 r. promulgowano ordonans z Villers-Cotterêts ${ }^{10}$ (192 artykuły), na mocy którego wprowadzono

3 Ordonnances des roys de France de la troisième race, recueillies par ordre chronologique, red. E. de Laurière, t. I, Paris 1723, s. 679 i n.

4 Zwłaszcza ordonans z grudnia 1355 r.; ibidem, t. III, s. 19 i n. oraz z marca 1356 r.; ibidem, s. $121 \mathrm{in.}$

5 Por. A. Coville, L'ordonnance cabochienne (26-27 mai 1413), publiée avec une introduction et des notes, Paris 1891.

6 Ordonnances..., t. XIV, s. 284 i n.

7 O zarządzonej na mocy niniejszego ordonansu oficjalnej redakcji coutume'ów wspominali m.in.: K. Koranyi, Powszechna..., t. III, s. 144; K. Koranyi, Powszechna historia prawa, oprac. K. Sójka-Zielińska, s. 195; T. Maciejewski, op.cit., s. 234; M. Sczaniecki, op.cit., s. 120; K. Sójka-Zielińska, Historia..., s. 61; idem, Kodeks..., s. 21;

${ }^{8}$ Ordonnances..., t. XX, s. 386 i n.

9 Ordonnance rendue, en conséquence d'une assemblée de notables, sur la justice et la police du royaume; Ibidem, t. XXI, s. 177 i n.

${ }^{10}$ Recueil général des anciennes lois françaises, depuis l'an 420 jusqu'à la Révolution de 1789 , [red.] F.A. Isambert, Decrusy, Armet, t. XII, Paris 1828, s. 600 i n. Por. także J. Foyer, L'Ordonnance de Villers-Cotterêts, [w:] Comptes rendus des séances de l'Académie des Inscriptions et Belles-Lettres, $133^{\mathrm{e}}$ année, nr 3/1989, s. 636-646. 
m.in. obowiązek sporządzania oficjalnych dokumentów w języku francuskim, a nie po łacinie ${ }^{11}$. Wiele $\mathrm{z}$ postanowień $\mathrm{w}$ nim zawartych stanowiło znaczący krok w kierunku ideologicznej i językowej unifikacji Francji, doczekał się więc licznych komentarzy. Niezwykle istotną rolę odegrały także ordonanse związane z nazwiskiem kanclerza Michela de l'Hôpitala. Trzy najważniejsze wydane zostały w efekcie realizacji postulatów sformułowanych na posiedzeniach Stanów Generalnych w 1560 r. w Orleanie. Były to ordonanse z Orleanu z 1561 r. ${ }^{12}$, z Roussillon z 1563 r. ${ }^{13}$ i z Moulins z 1566 r. ${ }^{14}$ Natomiast obrady Stanów w 1576 r. przyniosły promulgację nowego ordonansu z Blois (363 artykuły) z 1579 r. ${ }^{15}$ Serię zamykał wielki ordonans z 1629 r. ${ }^{16}$, zredagowany w efekcie starań Michela de Marillaca, stanowiący syntezę postanowień podjętych w trakcie posiedzeń Stanów Generalnych w 1614 r. i Zgromadzeń Notablów w 1617 i 1626 r. Było to dzieło znacznie bardziej obszerne niż akty dotychczas wydawane w efekcie królewskiej działalności ustawodawczej (461 artykułów). Zawierało wiele propozycji znaczących i użytecznych reform. Ale to właśnie jego reformatorski charakter wywołał opór parlamentów. Jego rejestracja uzależniona była od tak wielu poprawek, że było to jednoznaczne z odrzuceniem jego podstawowych założeń. Ośmieszano ordonans nazywając go „Kodeksem Michałka" (Code Michau, Code Michaud) i praktycznie nie przestrzegano jego przepisów.

$\mathrm{Na}$ mocy wspomnianych ordonansów udało się uregulować pewną liczbę istotnych instytucji w sposób, który pozostawił w systemie prawa francuskiego trwały ślad. Zawarcie małżeństwa unormowane zostało $\mathrm{w}$ ordonansie $\mathrm{z}$ Blois z 1579 r. (art. 40, 44, 45) i tym z 1629 r. (art. 39). Prowadzenie przez proboszczów parafii oficjalnych rejestrów zgonów, małżeństw i chrztów uregulowano na mocy ordonansu z 1539 r. (art. 50, 56), z 1579 r. (art. 40, 181) i z 1629 r. (art. 40). Praktykę tę zapoczątkowały instytucje kościelne, jednakże dopiero jej zalegalizowanie przez władzę królewską nadało rejestrom rękojmię wiary publicznej, nie

${ }^{11}$ Ordonans ten jest jednym z najstarszych aktów prawnych, wciąż częściowo obowiązujących we Francji, a jego art. 110 i słynny art. 111 (dotyczący stosowania języka francuskiego w dokumentach urzędowych) nie zostały nigdy derogowane; https:/www.legifrance.gouv.fr/affichTexte.do?cid Texte=LEGITEXT000006070939 [dostęp: 15.10.2017].

12 Recueil général..., t. XIV, s. 63 i n.

${ }^{13}$ Ibidem, s. 160 i n. Pomimo, iż datowany był w Paryżu, ordonans niniejszy powszechnie (również przez samego ustawodawcę) nazywano ordonansem z Roussillon. Wynika to z faktu, iż zarejestrowany został wraz z deklaracją wydaną w Roussillon 9 sierpnia 1564 r. Ibidem, s. 173 i n.

${ }^{14}$ Ibidem, s. $189 \mathrm{i} \mathrm{n.}$

15 Ibidem, s. 380 i n. Mimo, iż niniejszy ordonans również datowany był w Paryżu powszechnie określa się go mianem ordonansu z Blois, ze względu na fakt, iż jego wydanie nastąpiło w związku z obradami Stanów Generalnych w Blois w 1576 r.

16 Ibidem, t. XVI, s. 223 i n. 
dopuszczając co do zasady innych rodzajów dowodów zawarcia małżeństwa, narodzin czy zgonu. Na mocy ordonansu z Moulins z 1566 r. (art. 54) wprowadzono ograniczenie dowodu ze świadków, które powtórzone zostało następnie w Kodeksie cywilnym z 1804 r. (art. 1341). W okresie wcześniejszym, zgodnie z zasadą témoins passent lettres, dowód ze świadków miał większą wartość niż dokumenty. W ordonansie z Moulins wprowadzono natomiast zakaz jego przeprowadzania dla udowodnienia zawarcia kontraktu powyżej 100 liwrów i dopuszczania zeznań przeciwko lub ponad osnowę dokumentu. Na mocy ordonansu z Villers-Cotterêts (art. 132, 133) i z Moulins (art. 58) usankcjonowano obowiązek rejestracji darowizn w kancelariach sądów królewskich. Substytucje fideikomisarne zostały ograniczone i wprowadzono obowiązek ich ogłaszania na mocy ordonansu z Orleanu (art. 58) i z Moulins (art. 57). Zachodzące natomiast od XIII w. przeobrażenia w procedurze karnej ukonstytuowane zostały w ordonansach z 1498 i 1539 r. ${ }^{17}$

II. Wielkie Ordonanse Ludwika XIV i XV prezentowały całkowicie odmienny charakter od wszystkich ordonansów o charakterze ogólnym poprzedniego okresu. Stanowiły kodeksy w ścisłym tego słowa znaczeniu. Zawierały kompleksowe, usystematyzowane i szczegółowe regulacje w zakresie poszczególnych dziedzin prawa. Redagowały je komisje składające się z niewielkiej liczby kompetentnych członków, których efekty działania zachowywane były w postaci cennej dokumentacji z prac przygotowawczych. Działalność kodyfikacyjna prowadzona później w okresie Konsulatu i I Cesarstwa była analogiczna w zakresie formy i metody postępowania. Ordonanse tego typu, właściwe dla historii prawa francuskiego, stanowily ewenement na skalę światową. Wydawano je w okresie ancien régime'u, kodyfikując wybrane dziedziny prawa na mocy jednolitych aktów prawnych obowiązujących na obszarze całego państwa. Powstawały przy zrozumieniu twórczej roli przepisów prawa w modyfikowaniu rzeczywistości ${ }^{18}$. Były przedmiotem zainteresowania wielu znamienitych komentatorów, którzy precyzowali i wyjaśniali zawarte w nich normy. Co więcej, stanowiły wzór w zakresie formy i treści dla XIX-wiecznych kodeksów.

To dzieło kodyfikacyjne realizowane etapowo w formie ordonansów wydawane było w okresie rządów dwóch władców: Ludwika XIV pod wpływem Jeana Baptiste'a Colberta oraz Ludwika XV pod kierownictwem kanclerza Henri'ego Françoisa d'Aguesseau.

J.B. Colbert zainspirował Ludwika XIV do odegrania w historii Francji roli wielkiego legislatora, sugerując przy tym gotowy plan stworzenia nowego usta-

\footnotetext{
${ }_{17}$ Por. przyp. 1.

18 Por. Mémoire sur la reformation de la justice, [w:] P. Clément, Lettres, instructions et mémoires de Colbert, publiès d'après les ordres de l'empereur, t. VI: Justice et police, affaires religieuses, affaires diverses, Paris 1869, s. 5-12.
} 
wodawstwa $^{19}$. Do jego realizacji planował zatrudniać dwie kategorie osób: wybitnych praktyków prawa i członków rady królewskiej. Ci pierwsi, przy udziale kilku drugich, mieli opracowywać projekt, dyskutowany następnie na łonie Rady Sprawiedliwości (Conseil de justice), składającej się ze starannie wybranych radców stanu i współpracowników kanclerza Królestwa Francji (maîtres des requêtes). Parlamenty i organy sądownicze miały być od tych prac odsunięte. Co do zasady ten model postępowania był stosowany, w przypadku jednakże redakcji dwóch pierwszych ordonansów z roku 1667 i 1670, ze znaczącymi odstępstwami.

Ordonansem nad którym podjęto prace $\mathrm{w}$ pierwszej kolejności był akt z zakresu procedury cywilnej. Projekt zredagowany został przez komisję złożoną $\mathrm{z}$ adwokatów i radców stanu, którym przewodniczył Henri Pussort, wuj J.B. Colberta. Wszystko było gotowe do złożenia w Radzie Sprawiedliwości, kiedy interwencje pierwszego prezydenta Parlamentu Paryża Guillaume'a de Lamoignona nadały przedsięwzięciu trochę inny kierunek. Próbował on przeforsować u króla realny udział sędziów w reformie procedury cywilnej, zgłaszając jednocześnie własne propozycje w tym zakresie. Ludwik XIV wyraźnie podtrzymywał kierownictwo J.B. Colberta ${ }^{20}$, niemniej jednak członkowie Parlamentu zostali dopuszczeni do finalnego odczytywania projektu przed mieszaną komisją, w której skład wchodzili oni sami, radcy stanu i maîtres des requêtes. Sprawozdania z tych posiedzeń zostały opublikowane ${ }^{21}$. Najwięcej uwag wygłosili H. Pussort i G. de Lamoignon. Przygotowany w ten sposób projekt poddany został rewizji Rady Sprawiedliwości, a następnie promulgowany jako Ordonnance civile touchant la réformation de la justice w kwietniu $1667 \mathrm{r}^{22}$ Stanowił kompleksowy i drobiazgowy kodeks procedury cywilnej. Podzielony został na 35 tytułów. Podstawowym celem, jaki postawili sobie redaktorzy, było ujednolicenie postępowania, jednoznaczne określenie obowiązujących $w$ nim zasad oraz ograniczenie formalności i niepotrzebnych pism. W okresie późniejszym wydawano różne ordonanse uzupełniające, m.in. ordonans z sierpnia 1669 r. regulujący kwestie ewokacji, listów committimus i postanowień w sprawie właściwości sądu ${ }^{23}$. Do najznamienitszych komentatorów ordonansu z 1667 r. należeli Daniel Jousse ${ }^{24}$ i Robert-Joseph

19 Por. ibidem.

20 Vie de M. Premier Président de Lamoignon, écrit d'après le mémoires du temps et les papiers de la famille, Paris 1781, s. xxx; F. Monnier, Guillaume de Lamoignon et Colbert. Essai sur la législation française au XVII siècle, Paris 1862, s. 71.

${ }^{21}$ Procès-verbal des conférences tenues par ordre du Roi pour l'examen des articles de l'Ordonnance civile du mois d'Avril 1667 et de l'Ordonnance criminelle du mois d'Avril 1670, seconde édition, corrigée et augmentée, Paris 1700.

${ }^{22}$ Recueil général..., t. XVIII, s. 103 i n.

${ }^{23}$ Ibidem, s. 341 i n.

${ }^{24}$ D. Jousse, Nouveau commentaire sur l'ordonnance civile du mois d'avril 1667. Nouvelle édition, corrigée et augmenté, t. 1-2, Paris 1757. 
Pothier $^{25}$. Stanowił on podstawę prac komisji napoleońskiej redagującej Kodeks procedury cywilnej z 1806 r., w którego treści skopiowano znaczną część rozwiązań zaczerpniętą z ordonansu Ludwika XIV.

Ordonans o postępowaniu karnym (Ordonnance criminelle) ${ }^{26} \mathrm{z}$ sierpnia $1670 \mathrm{r}^{27}$ został opracowany i zredagowany podobnie jak poprzedni. Także więc $\mathrm{w}$ jego przypadku przygotowany wstępnie projekt trafił pod obrady mieszanej komisji, z których sprawozdania zostały opublikowane ${ }^{28}$. Stanowił obszerny akt prawny, w którym po raz pierwszy wszelkie formalności związane ze śledztwem w postępowaniu karnym zostały drobiazgowo uregulowane. Na organy prowadzące nałożono obowiązek sporządzania wszystkich dokumentów ze znacznie większą skrupulatnością, co było niezwykle istotne, gdyż wyrok wydawano prawie wyłącznie na ich podstawie. W praktyce było to jednak trudne do osiągnięcia, szczególnie w sądach niższego rzędu. Starano się również obniżyć koszty i zminimalizować popełniane $\mathrm{w}$ trakcie postępowania nadużycia. Przyjęta jednakże $\mathrm{w}$ ordonansie wersja procedury karnej była ekstremalnie rygorystyczna. Potęgowała to obowiązująca w trakcie postępowania zasada tajności i zakaz udzielania oskarżonemu porady (poza nielicznymi wyjątkami). Złożenie przysięgi przez oskarżonego było bezwzględnie wymagane. Najczęściej jednak wpływało negatywnie na jego sytuację ze względu na nieuniknioną konfrontację ze świadkami oskarżenia. Na mocy ordonansu przyjęto bowiem zasadę, iż każdy świadek odmawiający konfrontacji zostanie skazany za składanie fałszywych zeznań i krzywoprzysięstwo ze względu na fakt, iż miała ona mieć miejsce po dwukrotnych zeznaniach przed sądem składanych pod przysięgąą. Z protokołów z obrad nad projektem wynika, że H. Pussort jawił się jako nieelastyczny zwolennik wszystkich rygoryzmów w przeciwieństwie do G. de Lamoignona, który przeciwko nim protestował. Jednoznacznie krytykował instytucję przysięgi oskarżonego, zakaz porady, system konfrontacji i stosowania tortur, które zresztą nie zostały w przepisach jednoznacznie uregulowane. Sposób ich przeprowadzania był więc w praktyce zróżnicowany. Żądania jednak wprowadzenia w tym zakresie jednolitej regulacji H. Pussort skwitował w zadziwiający sposób: „opis, którego należałoby dokonać, byłby nieprzyzwoity”30. Ordonans z 1670 r. doczekał się wielu komen-

${ }^{25}$ Euvres de Pothier, wyd. J.J. Bugnet, t. X, Traité de la procédure civile, Traité de la procédure criminelle, Paris 1890.

${ }^{26}$ K. Koranyi słusznie uznał go za „ukoronowanie całej działalności ustawodawczej XVI i XVII w. w dziedzinie procedury karnej”; idem, op. cit., t. III, s. 298. Jak trafnie zauważył A. Dziadzio, „stanowił [on] w pełni rozwiniętą kodyfikację formalnego prawa karnego”. Idem, op.cit., s. 139.

27 Recueil général..., t. XVIII, s. 371 i n.

28 Przyp. 21.

${ }^{29}$ Szerzej na temat całego postępowania: A. Esmein, op.cit., s. 212-396.

${ }^{30}$ Procès-verbal..., s. 224. 
tarzy, wśród których warto wymienić przede wszystkim te autorstwa D. Jousse'a ${ }^{31}$ i Pierre'a-Françoisa Muyarta de Vouglans ${ }^{32}$. Po pewnym złagodzeniu najbardziej rygorystycznych rozwiązań, posłużył za model części Kodeksu postępowania karnego z 1808 r., dotyczącej śledztwa wstępnego, które w efekcie pozostało tajne; przepisy kodeksu dotyczące postępowania przed sądem wyrokującym miały natomiast już swoją genezę $\mathrm{w}$ prawie rewolucyjnym ${ }^{33}$.

Tylko w przypadku ordonansów z 1667 r. i 1670 r. członkowie Parlamentu paryskiego zostali dopuszczeni do prac przygotowawczych. W przypadku pozostałych oryginalny plan J.B. Colberta realizowany był bez żadnych zakłóceń.

Wydanie Ordonansu o handlu (Ordonnance du commerce) z marca 1673 r. ${ }^{34}$ było długo przygotowywane przez J.B. Colberta. Na początku lat siedemdziesiątych zlecił kilku kompetentnym osobom przygotowanie memoriałów w tym zakresie. Wśród nich był J. Savary, ceniony kupiec z długoletnią praktyką, który również publikował na temat prawa handlowego ${ }^{35}$. J.B. Colbert utworzył Radę Reformy (Conseil de réforme), której przewodniczył co prawda H. Pussort, ale decydujący głos w sprawach merytorycznych należał do Jacques'a Savary'ego. Projekt stanowił bowiem punkt wyjścia do prac nad ordonansem. Zredagowany przez Radę akt stanowił pierwszy kodeks handlowy na świecie, zawierał jednakże przepisy dotyczące wyłącznie handlu lądowego. Handel morski wraz z innymi instytucjami prawa morskiego uregulowany został w Ordonansie o marynarce

${ }^{31}$ D. Jousse, Nouveau commentaire sur l'ordonnance criminelle du mois d'août, avec un abrégé de la justice criminelle, Paris 1752.

${ }^{2}$ P.-F. Muyart de Vouglans, Institutes au droit criminel, ou principes généraux sur ces matières, suivant le droit civil, canonique, et la jurisprudence de royaume; avec un Traité particulier des crimes, Paris 1768; idem, Instruction crminelle suivant les loix et ordonnances du Royaume. Divisée en trois parties. Partie première: Instruction suivant l'ordonnance de 1670, et les déclarations rendues en conséquence. Partie seconde: Instruction suivant la nouvelle ordonnance de 1737, sur le faux principal, le faux incydent et la reconnaissance des écritures et signatures privées en matière criminelle. Partie troisième: Instruction conjointe entre le juge d'église et le juge royal, pour le cas privilégié. Pour servir de suite aux Institutes au droit criminel, et au Traité des crimes, du même auteur; Paris 1762; idem, Les loix criminelles de France, dans leur ordre naturel dédiées au roi, Paris 1780 .

${ }^{33}$ A. Esmein, op.cit., s. 527-558.

${ }^{34}$ Recueil général..., t. XIX, s. 92 i n.

${ }_{35}$ Por. Vie de M. Savary, [w:] J. Savary, Le parfait négociant, ou instruction générale pour ce qui regarde le commerce des marchandises de France, et de pays étrangers; pour la banque, le change, et rechange; pour les sociétés ordinaires, en commandites, et anonymes; pour les faillites, banqueroutes, séparations, cessions et abandonnements de bien; pour la manière de tenir les livres journaux d'achats, de ventes, de caisse et de raison; des formulaires de lettres et billets de change, d'inventaire, et de toutes sortes de sociétés; comme aussi plusieurs parères au avis et conseils sur diverses matières des commerce très-importantes, nouvelle édition, [wyd.] J. Savary des Bruslons, P.L. Savary, Paris 1777 , t. I, s. xxi-xxiv. 
(Ordonnance de la marine) z kwietnia $1681 \mathrm{r} .{ }^{36}$ Oba ordonanse doczekały się komentarzy czołowych autorów, ten z 1673 r. - D. Jousse'a ${ }^{37}$, Françoisa de Boutari$\mathrm{ca}^{38}$ i R.J. Pothiera ${ }^{39}$, ten natomiast z 1681 r. - R.J. Pothiera ${ }^{40}$ i przede wszystkim René-Josué Valina ${ }^{41}$. Normy zawarte w jednym i drugim zostały w dużej części skopiowane w trakcie redakcji Kodeksu handlowego z 1807 r.: księga I i IV bazowała na przepisach Ordonansu o handlu, księga II natomiast na rozwiązaniach dotyczących handlu morskiego zawartych w ordonansie z $1681 \mathrm{r}$. Warto także zaznaczyć, że w zakresie prawa morskiego w kwietniu 1689 r. doszło do promulgacji innego wielkiego ordonansu (Ordonnance concernant les armées navales et les arsenaux de marine $)^{42}$. Był on niezwykle obszerny, składał się z 23 ksiąg, dotyczył jednak głównie marynarki wojennej. Przewidywał m.in. w celu poboru załogi system klas (I-VIII) stanowiący pierwowzór obowiązującego obecnie systemu tzw. inscription maritime.

Ordonans o wodach i lasach (Ordonnance portant réglement pour les eaux et forêts) z sierpnia $1669 \mathrm{r}{ }^{43}$, z drobnymi nowelizacjami wydany później jako Kodeks leśny (Code forestier) w 1827 r., opracowany został na podstawie memoriałów przygotowanych przez wykwalifikowanych urzędników przydzielonych do przeprowadzenia reformy $w$ tym zakresie.

${ }^{36}$ Recueil général..., t. XIX, s. 282 i n.

${ }^{37}$ D. Jousse, Nouveau commentaire sur l'ordonnance du commerce du mois de mars 1673, Paris 1755.

${ }^{38}$ F. de Boutaric, L'Explication de l'ordonnances de Louis XIV. Roi de France et de Navarre concernant le commerce, Toulouse 1743. Ten sam autor wydał także komentarze do ordonansów z 1667 r. i 1670 r.: idem, Explication des ordonnances de Louis XIV sur les matières civiles et les matières criminelles Toulouse 1745.

${ }^{39}$ Euvres de Pothier, wyd. J.J. Bugnet, t. IV, Traités du contrat de louage, du contrat de bail à rente, du contrat de société, des cheptels, des contrats de louages maritimes, du contrat de change, Paris 1890.

${ }^{40}$ Ibidem; Euvres de Pothier, wyd. J.J. Bugnet, t. V, Traités du prêt a usage, du précaire, du prêt de consomption, de l'usure, du promutuum et de l'action conditio indebiti, des contrats de dépot, de mandat (et quasi-contrat negotiorum gestorum), d'assurance, de pr'et a la grosse aventure, de jeu et de nantissement, Paris 1890.

${ }^{41}$ R.J. Valin, Nouveau Commentaire Sur L'ordonnance De La Marine Du Mois D'août 1681, Où se trouve la Conférence des anciennes Ordonnances, des Us \& Coutumes de la Mer, tant du Royaume que des Pays étrangers, \& des nouveaux Règlements concernant la Navigation \& le Commerce maritime. Avec des Explications prises de l'esprit du Texte, de l'Usage, des Décisions des Tribunaux \& des meilleurs Auteurs qui ont écrit sur la Jurisprudence nautique. Et des Notes historiques \& critiques, tirées de la plupart des divers Recueils de Manuscrits conservés dans les dépôts publics. Dédié à S.A.S. Mgr. le Duc de Penthièvre, Amiral de France. Nouvelle Edition, revue, corrigée \& augmentée, Rochelle 1766.

${ }^{42}$ Recueil général..., t. XX, s. 73.

${ }^{43}$ Ibidem, t. XVIII, s. 219 i n. Por. komentarz D. Jousse'a, Commentaire sur l'ordonnance des eaux et forêts, du mois d'août 1669, Paris 1772. 
Edykt z marca $1685 \mathrm{r}^{44} \mathrm{w}$ sprawie niewolników (Édit du roi touchant la discipline des esclaves négres des îles de l'Amerique française), nazywany również Czarnym kodeksem (Code noir), stanowił pierwszy akt prawny w całości stosowany wobec czarnych i białych przedstawicieli populacji. Obejmował swoim zakresem regulację kwestii społecznych, wyznaniowych i patrymonialnych pomiędzy tymi grupami. Zredagowany został na podstawie memoriałów sporządzonych przez administratorów wysp, nad którymi prace zlecono już w 1681 r. Po przywróceniu przez Napoleona niewolnictwa, stosowano go również w XIX wieku.

Warto również wspomnieć o akcie poświęconym węższej materii i o trwałości bardziej efemerycznej - Edykcie z marca 1673 r. (Édit portant établissement de greffes pour l'enregistrement des oppositions des créanciers hypothécaires $)^{45}$, na mocy którego zamierzano wprowadzić rejestrację sprzeciwów wierzycieli hipotecznych w kancelariach sądowych. Intencją ustawodawcy było ustanowienie zasady publikowania informacji na temat hipotek, które w ówczesnym stanie prawnym, ze względu na wpływ prawa rzymskiego, były tajne, co negatywnie wpływało na rozwój kredytu. Jednak próby uchwalenia innych rozwiązań w tym zakresie spotkały się z przemożnym oporem ze strony szlachty, która nie była zainteresowana ujawnianiem obciążeń swoich dóbr. Presja była tak silna, że król był zmuszony ustąpić i w kwietniu 1674 r. odwołał edykt ${ }^{46}$.

W okresie rządów Ludwika XV doszło do uchwalenia kolejnej serii kodyfikacji z inicjatywy kanclerza H.F. d'Aguesseau. Jego zamierzeniem również była reforma całości systemu prawa i zredukowanie licznych źródeł do wyłącznego i usystematyzowanego zbioru ${ }^{47}$. Zlecał kompetentnym osobom lub organom sporządzanie stosownych memoriałów, konsultował się z parlamentami i ustanowił centralną komisję działającą na zasadzie jego prywatnej rady. W efekcie opracowana została pewna liczba ustaw, będących jedynie fragmentem kolosalnego dzieła, o którym marzył kanclerz. Udało mu się jednak wprowadzić jednolite, obowiązujące na terytorium całego państwa, ustawodawstwo, m.in. w zakresie prawa cywilnego materialnego. Prace nad kodyfikacją tej dziedziny prowadzone były już w okresie rządów Ludwika XIV (powstał m.in. projekt autorstwa pierwszego prezydenta Parlamentu paryskiego G. de Lamoignona, który jednakże nie

${ }^{44}$ Recueil général..., t. XIX, s. 494 i n.

${ }^{45}$ Ibidem, s. 73 i n.

${ }^{46}$ Édit portant révocation de celui de mars 1673 sur les hypothèques; Recueil général..., t. XIX, s. 133. Por. także na temat tej kwestii: Cuvres complètes du chancelier d'Aguesseau, nouvelle édition, wyd. J.M. Pardessus, Paris 1819, t. IX, s. 279 i n.

${ }^{47}$ F. Monnier, Le chancelier d'Aguesseau, sa conduite et ses idées politique, son influence sur le mouvement des esprits pendant la première moitié du XVIII siècle, avec des documents nouveaux et plusieurs ouvrages inédits du chancelier, Paris 1860, s. 285. 
uzyskał aprobaty królewskiej) ${ }^{48}$. H.F. d'Aguesseau z góry zakładał, że projektowany akt prawny nie powinien regulować wszystkich najdrobniejszych kwestii w danej dziedzinie, a jedynie koncentrować się na ogólnych zagadnieniach, najbardziej istotnych z punktu widzenia porządku publicznego, co miało przede wszystkim ujednolicić linię orzeczniczą parlamentów francuskich. Największe znaczenie miały następujące usystematyzowane i kompleksowe akty prawne: (1) Ordonans o darowiznach z lutego $1731 \mathrm{r}^{49}$ (Ordonnance pour fixer la jurisprudence sur la nature, la forme, les charge \& les conditions des donations), w preambule do którego ustawodawca wyraźnie zaznaczał, iż ten jednolity akt prawny obowiązujący w całym królestwie stanowi jedynie „pierwszy przykład realizacji planu [stworzenia zbioru ustaw/praw], jaki przedłożyliśmy" (premier exemple de l'exécution du plan [de corps des lois] que nous nous sommes proposés); (2) Ordonans o testamentach z sierpnia $1735 \mathrm{r}^{50}$ (Ordonnance concernant les testaments), wydany, podobnie jak poprzedni w celu likwidacji „odmienności, różnorodności w orzecznictwie" (variété, diversité de jurisprudence) ${ }^{51}$; (3) Ordonans o substytucjach fideikomisarnych z sierpnia $1747 \mathrm{r}^{52}$ (Ordonnance concernant les substitutions). Normy zawarte w tych trzech aktach prawnych zostały w dużej mierze inkorporowane do treści Kodeksu cywilnego z 1804 r. ${ }^{53}$ Poza tym, wydany został (4) Ordonnance concernant le faux principal et le faux incident et la reconnaissance des écritures et signatures en matière criminelle z lipca $1737 \mathrm{r}^{54}$, regu-

48 Szerzej: A. Klimaszewska, Z dziejów..., s. 11-28.

${ }^{49}$ Recueil général..., t. XXI, s. 343 i n. Por. także: H. Regnault, Les ordonnances civiles $d u$ chancelier Daguesseau. Les donations et l'ordonnance de 1731, Paris 1929.

${ }^{50}$ Recueil général..., t. XXI, s. 386 i n. Por. także: H. Regnault, Les ordonnances civiles du chancelier Daguesseau. II : Les testaments et l'ordonnance de 1735, Paris 1938.

${ }^{51} \mathrm{O}$ ile jednak w przypadku ordonansu o darowiznach podjęto się w pierwszej kolejności jednolitego i kompleksowego uregulowania tej kwestii ze względu na ,albo prostotę, albo niewielką sprzeczność, jaka w niej istnieje pomiędzy zasadami prawa rzymskiego i zasadami prawa francuskiego " (soit par sa simplicité, soit par le peu d'opposition, qui s'y trouve entre les principes du droit Romain et ceux du droit français), to z kolei przy ordonansie o testamentach zaznaczano konieczność ustawowego uregulowania materii z powodu „sprzeczności, jaka istnieje w tym względzie pomiędzy duchem prawa rzymskiego [...] i duchem prawa francuskiego" (l'opposition qui règne à cet égard entre l'esprit du droit romain [...] et celui du droit français). Por. preambuły do obu ordonansów. Szerzej na temat ordonansów Ludwika XV: J.A. Sallé, L'esprit des ordonnances et des principaux édits et déclarations de Louis XV en matière civile, criminelle et bénéficiale, Paris 1759.

${ }^{52}$ Recueil général..., t. XXII, s. 193 i n.

${ }^{53}$ Por. L. Tripier, Les codes français collationnés sur les éditions officielles contenant: 1 \%a conférence des articles entre eux; $2^{\circ}$ sous chaque article, les textes tant anciens que nouveaux qui les expliquent, les complétent ou les modifient; $3^{\circ}$ un supplément par ordre alphabétique et chronologique renfermant, outre les lois les plus usuelles, celles exigées pour les thèses et les textes anciens qui sont encore en vigueur; $4^{\circ}$ une table alphabétique renvoyant aux lois et aux pages ou elles sont reproduites, et les seuls où sont rapportés les textes du droit ancien et intermédiaire nécessaires à l'intelligence des articles, Paris 1848.

${ }^{54}$ Recueil général..., t. XXII, s. 1 i n. 
lujący kwestie fałszerstw, uznawany za dzieło niemal doskonałe pod względem techniki legislacyjnej $\mathrm{w}$ zakresie regulowanej materii. Przepisy $\mathrm{w}$ nim zawarte zostały wykorzystane niemal w całości i powtórzone w Kodeksie procedury cywilnej z 1806 r. oraz w Kodeksie procedury karnej z 1808 r.

Wyraźnie należy więc podkreślić, że Francja ancien régime'u niepozbawiona była generalnych, jednolitych aktów prawnych w sposób kompleksowy regulujących wybrane dziedziny prawa i obowiązujących na terytorium całego państwa. Wydano wówczas kodeks procedury cywilnej, kodeks postępowania karnego, kodeks handlowy i morski, uregulowano nawet niektóre obszary prawa cywilnego. To, czego jednak się nie udało opracować ani do czego nawet się nie zbliżono, to kodeks karny.

Szczególnie więc w tym kontekście nieuzasadnione wydaje się, jak trafnie podkreślał Wacław Uruszczak, stawianie sztucznych granic na linii rozwojowej prawa oraz ograniczanie desygnatów nazwy kodeks i kodyfikacja do „nowoczesnych tworów w rodzaju francuskiego Code civil z 1804 r." i tzw. epoki wielkich kodyfikacji ${ }^{55}$. Przy tym uznawanie za przesłanki wyróżniające nowoczesne (oświeceniowe) pojęcie kodyfikacji ${ }^{56}$, w przeciwieństwie do działalności wieków wcześniejszych skoncentrowanej na konieczności spisywania praw oraz „potrzebie zbierania praw rozproszonych i trudno dostępnych", woli tworzenia kodeksów w oparciu o abstrakcyjne zasady sprawiedliwości i idei budowania prawa od podstaw ${ }^{57}$, wzbudza uzasadnione wątpliwości, szczególnie, że przynajmniej ta ostatnia przesłanka $\mathrm{z}$ całą pewnością nie została zrealizowana w przypadku napoleońskich prac kodyfikacyjnych. Choć z założenia myśliciele Oświecenia „nie wyobrażali sobie możliwości opracowania kodeksu, który byłby jedynie zbiorem przepisów dotychczasowych" 58 , trend ten, jak powszechnie wiadomo,

55 W. Uruszczak, Europejskie kodeksy prawa doby renesansu, „Czasopismo Prawno-Historyczne", t. XL, z. 1/1988, s. 59-90 (62); idem, Les codes de droit en Europe à l'époque de la Renaissance, [w:] La codification européenne du Moyen-Age au siècle des Lumières, [red.] S. Salmonowicz, Warszawa 1997, s. 69-102 (73). Por. także uwagi L. Górnickiego, O pojęciu i znaczeniu wielkich kodeksów cywilnych w związu z książka Katarzyny Sójki-Zielińskiej Wielkie kodyfikacje cywilne. Historia $i$ wspótczesność, „Kwartalnik Prawa Prywatnego”, r. XXI: 2012, z. 1, s. 52-89 (zwłaszcza na s. 56) oraz przytoczoną tam bibliografię.

${ }^{56}$ Por. także uwagi na temat pojęcia kodyfikacji w znaczeniu ścisłym dla określenia ruchu kodyfikacyjnego zapoczątkowanego w dobie Oświecenia: K. Sójka-Zielińska, Codification, [w:] Dictionnaire Encyclopédique de Théorie et de Sociologie du Droit, [red.] A.J. Arnaud, Paris-Bruxelles 1988, s. 70; idem, Kodeks..., s. 27-28; idem, Wielkie kodyfikacje cywilne. Historia i wspótczesność, Warszawa 2009, s. 29. Por. również W. Szafrański, Pojęcie kodyfikacji w ujęciu historycznym, [w:] Prawo wobec wyzwań wspótczesności, [red.] P. Wiliński, t. II, Poznań 2005, s. 107 i n.

${ }^{57}$ S. Salmonowicz, Od Justyniana do Kodeksu Napoleona. Rozważania nad problematyka i terminologia zbiorów prawnych feudalnej Europy, [w:] idem, O rzemiośle recenzenta. Studia z warsztatu historyka, Warszawa 1999, s. 23 (przedruk z „Czasopisma Prawno-Historycznego”, t. XXI, z. 1/1969, s. 184-195 [195]).

${ }^{58}$ Ibidem. 
nie stał na przeszkodzie, by uwzględniając (czasami wybiórczo) wymogi najnowszych reform, z przepisów dotychczasowych obficie jednak czerpać. Z pewnością w każdym razie nie krępował on napoleońskich komisji kodyfikacyjnych, inkorporujących do treści XIX-wiecznych kodeksów wiele postanowień ancien-régime'owych ordonansów. Nie zakłóca to wcale powszechnego uznawania je za kodeksy sensu stricto. Warto przy tym podkreślić, iż ordonanse Ludwika $\mathrm{XIV}^{59} \mathrm{z}$ jednej strony wprowadzały różnego rodzaju reformy, $\mathrm{z}$ drugiej zaś stanowiły zwieńczenie niejednokrotnie wielowiekowej ewolucji poszczególnych zasad i instytucji; podobnie jak kodeksy napoleońskie, konstytuujące zaszłe przeobrażenia społeczne, polityczne i gospodarcze, nawet jeżeli miały one charakter bardziej gwałtowny. Niezwykle trudno przy tym obiektywnie oceniać poziom realizacji pierwszej przesłanki - woli tworzenia kodeksów w oparciu o abstrakcyjne zasady sprawiedliwości. Na jakiej metodologicznie obiektywnej podstawie? Przykładowo, częstotliwość przywoływania idei powszechnej sprawiedliwości była porównywalna $\mathrm{w}$ preambułach, motywach i sprawozdaniach $\mathrm{z}$ prac legislacyjnych nad obiema grupami aktów. Jej rozumienie oczywiście - różne, w zależności od epoki, której ducha oddawały; czy jednak przeszkadza w uznaniu Code civil z 1804 r. za kodeks dyskryminacja prawna mężatek czy dzieci pozamałżeńskich? Czy umniejszają wartości porewolucyjnych prac kodyfikacyjnych nad poszczególnymi dziedzinami prawa - nie zawsze sprzyjające abstrakcyjnym zasadom sprawiedliwości - pragmatyzm niejednokrotnie decydujący o przyjęciu bądź odrzuceniu poszczególnych rozwiązań czy towarzysząca tym pracom obsesja cesarza, dążącego do uzyskania (podobnie jak Ludwik XIV) miana wielkiego kodyfikatora? Nie ujmując autorom XIX-wiecznych ustaw żadnych ich zasług, szczególnie w zakresie postępu techniki legislacyjnej, zauważyć wypada, iż trudno, żeby akt prawny wydawany po obaleniu feudalizmu nie uwzględniał tego faktu; akt prawny, jak powszechnie wiadomo, mocno zakorzeniony przy tym $\mathrm{w}$ wielowiekowych tradycjach narodowych ${ }^{60}$. Kodeksy napoleońskie należy więc uznawać za kolejny rozdział w kodyfikacyjnej działalności we Francji w ścisłym tego słowa znaczeniu, która jednakże po raz pierwszy zrealizowana została przez Ludwika XIV ${ }^{61}$. Popularność tego zagadnienia w literaturze oświe-

${ }^{59}$ Nie podejmuję się na razie w tym zakresie komentować charakteru ordonansów Ludwika $\mathrm{XV}$; wymagałoby to bowiem kolejnych lat badań.

${ }^{60}$ Szerzej: K. Sójka-Zielińska, Kodeks..., s. 76 i n.

${ }^{61}$ Niezależnie od przyjętej przez polskich historyków prawa definicji kodeksu/kodyfikacji, m.in.: K. Sójka-Zielińska za Laroussem przyjmuje, iż au sens strict, la codification est définie comme 'l'oeuvre destinée à unifier, fixer, systématiser une législation en un corps de textes méthodiquement ordonné, ayant lui-même force de loi', idem, Codification..., s. 70; „kodyfikacja jest to zbiór przepisów prawa o charakterze większej całości, mający moc prawa obowiązującego na mocy samoistnego aktu prawnego", S. Salmonowicz, Kodyfikacje i myśl kodyfikacyjna XVII i XVIII wieku, [w:] Dzieje kodyfikacji prawa. Materiały na konferencję historyków prawa w Karpaczu, Poznań 
cenia i powszechność zjawiska w innych państwach europejskich jest bowiem niewystarczającym argumentem na określanie tym mianem we Francji dopiero ustaw XIX-wiecznych.

\section{ROYAL ORDINANCES IN FRANCE}

\section{Summary}

The issue of royal ordinances in France is not a subject avoided by Polish authors, especially in legal history textbooks. However, the information included in these books is fragmentary in its character, and some pieces require verification.

In this extensive legislative material one can distinguish specific ordinances (spéciales), which regulate single issues, as well as general ones (générales), which constitute acts pertaining to a wide spectrum of issues, or even detailed codes. The latter, i.e. the ordinances general in their character, can be further divided into two groups. The first of them encompasses the ordinances published between the 14th and the 17th century (I), while the second one includes the so-called Great Ordinances enacted during the reign of Louis XIV and Louis XV (II).

The purpose of the following publication is not to perform a detailed characteristic of the ordinances but, first and foremost, to show that although certain significant institutions were regulated by the ordinances from group I in a way which left a permanent mark on the French legal system, the Great Ordinances by Louis XIV and Louis XV, which represent a completely different character from all the previous general ordinances, constituted codes in the strict sense of the word. As a result of that codification work, performed in

1974, s. 144; „kodyfikacja sensu stricto jest to zbiór przepisów prawa o charakterze większej całości, powstały celem reformy prawa, a mający moc prawa obowiązującego na mocy samoistnego aktu prawnego”, W. Szafrański, op.cit., s. 113; „kodeksem nazwałbym pisany zbiór prawa (księga), komunikujący treść norm prawnych, obejmujący całość lub znaczną część systemu prawa danego państwa, uznany na mocy aktu ustawodawczego (ex lege) lub zwyczaju (ex consuetudine) za obowiązujące źródło (poznania) prawa”, W. Uruszczak, Europejskie..., s. 62-63. Ze względu na określenie „wyczerpująco” ordonanse Ludwika XIV nie do końca wypełniają znamiona definicji przyjętej przez E. Borkowską-Bagieńską (,kodeks to zbiór usystematyzowanych (wedle określonego kryterium) przepisów i norm, regulujących wyczerpująco jedną gałąź prawa (nawet jeśli jest to prawo materialne i procesowe), mające moc prawa obowiązującego mocą decyzji ustawodawcy, który tworzy go czerpiąc nie tylko z dotychczas obowiązujących przepisów, ale też tworząc je ex nihilo", E. Borkowska-Bagieńska, Między zbiorem a kodeksem. Refleksje o kodyfikacji i myśli kodyfikacyjnej Oświecenia, [w:] Historia integra. Księga pamiątkowa ofiarowana prof. Stanistawowi Salmonowiczowi w siedemdziesięciolecie urodzin, [red.] D. Janicka, R. Łaszewski, Toruń 2001, s. 93), regulowały bowiem wybrane dziedziny prawa kompleksowo, ale nie całkowicie wyczerpująco; niemniej jednak przesłanki „wyczerpującego regulowania jednej gałęzi prawa” nie spełnia także większość kodeksów XIX-wiecznych, jak choćby Code de commerce z 1807 r. czy ABGB. Por. także uwagi nt. kodyfikacji L. Górnickiego, Kodyfikacja prawa prywatnego, [w:] System prawa prywatnego. Prawo cywilne - część ogólna, t. I, [red.] M. Safjan, Warszawa 2012, s. 75-126 (zwł. § 9. Kodyfikacja i kodeks, s. 88 i n.). 
stages during the reign of two sovereigns, the ancien régime France did not lack general and unified legal acts, created with an understanding of the creative role of law in modifying the reality, regulating select fields of law in a comprehensive way and binding in the entire territory of the country. The code of civil procedure, the code of criminal procedure, as well as the commercial code and the maritime code, were enacted at the time. Some areas of civil law were also regulated. The only thing which was not elaborated, or even approached in those days, was the penal code.

Napoleonic codes should be therefore considered as the subsequent chapter of codification activities in France, carried out for the first time by Louis XIV. The popularity of this issue in the Enlightenment literature and the fact that it was a common phenomenon in other European countries is not a sufficient argument to justify applying this term only to those French acts which were enacted in the 19th century and afterwards.

(thumaczenie: Anna Klimaszewska)

\section{ORDONNANCES ROYALES EN FRANCE}

\section{Résumé}

Malgré que des auteurs polonais n'évitent pas, notamment dans les manuels d'histoire du droit, des questions d'ordonnances royales en France, les informations qu'elles fournissent sont fragmentaires, et certaines nécessitent une vérification. Parmi les nombreux textes législatifs, on distingue les ordonnances spéciales réglementant des questions spécifiques et les ordonnances générales qui concerne un large éventail de questions ou même constituent des codes détaillés. Les ordonnances générales peuvent être divisées en deux groupes: celles rendues du XIV ${ }^{e}$ au XVII ${ }^{\mathrm{e}}$ (I) et les Grandes Ordonnances de Louis XIV et XV (II).

L'objectif de cet ouvrage n'est pas de faire leur analyse détaillée, mais aussi de montrer que, même si les ordonnances du Groupe I ont permis de réglementer un certain nombre d'institutions fondamentales de telle façon qu'elles ont laissé leurs traces durables dans le droit français, les Grands Ordonnances de Louis XIV et XV, présentant un caractère totalement différent de toutes les ordonnances générales de la période précédente, constituaient les codes au sens strict du mot. Grâce à cette œuvre de codification, réalisée par étapes sous le règne des deux souverains, la France d'Ancien Régime disposait d'une législation générale et uniforme réglementant de manière globale des domaines de droit choisis et applicable dans tout le royaume, et qui a été fondée sur la compréhension du rôle créatif des lois dans la modification de la réalité. Le code de procédure civile, le code de procédure pénale, le code du commerce et de la marine ont été promulgués ; même certains domaines du droit civil ont été réglementés. Ce qui n'a pas été élaboré, c'était le code pénal. Cet article tente de prouver que les codes napoléoniens devraient être considérés comme un autre chapitre de l'œuvre de codification en France qui fut réalisée pour la première fois par Louis XIV. La popularité de cette question dans la littérature du siècle des Lumières et l'existence générale de ce phénomène dans d'autres pays européens est un argument insuffisant pour n'en nommer en France que des lois constituées en $\mathrm{XIX}^{\mathrm{e}}$ siècle. 